\title{
Perfil parasitário, proteínas plasmáticas totais e hematócrito de éguas em treinamento da raça Quarto de Milha
}

Aline Groto Barreiras ${ }^{[a]}$, Monise Furlamento Bueno ${ }^{[a]}$, Raquel Correia Leite ${ }^{[a]}$, Ingrid Bromerschenke[ ${ }^{[b]}$

[a] Centro Universitário do Norte Paulista (UNORP), São José do Rio Preto, SP, Brasil

[b] Universidade Estadual Paulista (UNESP), Jaboticabal, SP, Brasil

*Autor correspondente

e-mail: guingafl@hotmail.com

\section{Resumo}

O equino é muito utilizado como animal de esporte em competições de diversas modalidades. Os parasitas gastrointestinais causam redução de ganho de peso, de produtividade e predispõe os animais a doenças, acarretando em importantes prejuízos econômicos. Para minimizar os danos à saúde do animal, bem como a não redução da produtividade, busca-se níveis aceitáveis de infestação. Para detectar a presença destes parasitas, utiliza-se o teste do OPG (ovos por grama de fezes), que além de ser eficaz na avaliação do grau de infestação parasitária também é capaz de demonstrar a eficiência do controle parasitário. Nos exames de sangue, os valores fisiológicos do hematócrito variam entre as espécies e estão relacionados a algumas patologias como a anemia. As parasitoses podem levar o animal a uma hipoproteinemia, e que pode ser ocasionada por enteropatias e hemorragias causadas pelo parasitismo. 0 objetivo do estudo foi avaliar o OPG, proteína total e hematócrito de éguas em treinamento, naturalmente infestadas por endoparasitas. Foi utilizado um plantel da raça Quarto de Milha constituído por 12 éguas em treinamento, com média de idade de 2,9 anos, mantidas em um haras no município de Cedral/SP. As éguas recebiam ração duas vezes ao dia, e o volumoso era fornecido ad libitum. As colheitas das fezes foram realizadas de maneira não invasiva, imediatamente após a defecação, utilizando a porção do material que não tenha entrado em contato com o solo. As fezes foram armazenadas em sacos plásticos e acondicionadas em caixa isotérmica com gelo para transporte até o Laboratório de Microscopia da UNORP, onde as amostras foram processadas. Para análise das fezes foi utilizado o Método de Gordon e Whitlock (OPG). As coletas de sangue foram realizadas por venopunção da jugular com agulha vaccutainer 25 x 8. As amostras foram armazenadas em frascos com o anticoagulante ácido etilenodiamino tetra-acético (EDTA), identificadas e acondicionadas em caixa isotérmica com gelo para transporte até o Laboratório de Patologia Clínica da UNORP. Na análise 
hematológica foram realizadas as mensurações do Hematócrito (Ht) e da Proteína Plasmática Total (PPT), utilizando as técnicas de microhematócrito e de refratometria. Do total de 12 amostras avaliadas, uma $(8,33 \%)$ apresentou contagem de 400 OPG, uma amostra (8,33\%) 350 OPG, uma (8,33\%) 150 OPG, uma (8,33\%) 100 OPG, uma (8,33\%) 50 OPG e em sete amostras (58,33\%) não foram evidenciadas a presença de ovos nas fezes, pela técnica aplicada. A média aritmética do hematócrito foi de $38 \% \pm 3,4$ e da proteína plasmática total foi de 7,34 $\pm 0,49$. g/dL. Onze dos animais avaliados $(91,6 \%)$ apresentaram a contagem entre 0-350 OPG, correspondendo a um grau leve de infestação parasitária, o que pode acarretar em pouco ou nenhum efeito à saúde e produtividade do animal, e apenas um animal $(8,4 \%)$ apresentou uma contagem entre 400 - 950 OPG, sendo considerada uma infestação moderada, podendo causar efeitos à saúde e produtividade. Neste caso, já é recomendada a administração de anti-helmínticos no intuito de controlar a infestação. 0 valor de referência de hematócrito utilizado para a espécie equina encontra-se entre 32\% - 48\% e a concentração de proteína plasmática total encontra-se entre 6,0 g/dL - 8,5 g/dL. De acordo com o estudo realizado, todas as amostras analisadas apresentaram resultados condizentes com os valores de literatura, tanto em relação aos valores obtidos no hematócrito, quanto a proteína plasmática total. Não foram observadas alterações significativas nos valores de Ht e proteína plasmática total dos animais positivos para o OPG.

Palavras-chave: Equinos. OPG. Sangue. 